\title{
KEBERADAAN PERWAKILAN WILAYAH ADAT DI DEWAN PERWAKILAN RAKYAT PAPUA (DPRP) DALAM PERSPEKTIF KONTRAK SOSIAL DAN DALAM PERSPEKTIF REPRESENTASI DI PROVINSI PAPUA
}

\author{
Nelwan Ronsumbre ${ }^{1}$, Mohammad Benny ${ }^{2}$ \\ Program Pasca Sarjana Ilmu Pemerintahan \\ Fakultas Ilmu Sosial dan Ilmu Politik \\ Universitas Padjadjaran
}

Nelwan17001@mail.unpad.ac.id¹, Mohmmad.benny@unpad.ac.id²

\begin{abstract}
ABSTRAK
UU Otonomi khusus Papua yang diatur melalui UU No.21 Tahun 2001 telah memberikan kekhususan bagi Provinsi Papua untuk membentuk Dewan Perwakilan Wilayah Adat (DPWA) dalam kelembagaan legislatif daerah. Unsur keanggotaan DPWA adalah perwakilan masyarakat adat di wilayah Provinsi Papua yang terdiri atas 5 (lima) wilayah adat yang ditentukan berdasarkan kedekatan geografis dan kesamaan rumpun suku bangsa. Tujuan dari artikel ini adalah untuk menjelaskan fenomena keberadaan anggota perwakilan wilayah adat (DPWA) di Dewan Perwakilan Rakyat Papua (DPRP) dalam perspektif kontrak sosial menurut Thomas Hobes, John Locke dan J.J. Rousseau dan dalam perspektif representasi menurut Stuart Hall (2009). Artikel ini dikaji dan dianalisa dengan menggunakan metode kualitatif dimana data diperoleh melalui wawancara, dari dokumen, jurnal, literature maupun sumber online yang relevan dengan objek yang diteliti. Temuan dari kajian ini adalah dijelaskan bahwa antara dewan adat, dewan perwakilan wilayah adat dan masyarakat adat sebagai tiga elemen yang melakuan perjanjian kontrak sosial. Kontrak sosial yang dilakukan sifatnya tidak tertulis (unwritten contract) sehingga legitimasi dan eksistensinya tidak kuat. Representasi keanggotaan dewan adat sudah memenuhi kriteria secara teoritik yaitu berasal dari masyarakat adat, berbicara atas masyarakat adat dan berdiri di depan masyarakat adat. Penelitian ini selanjutnya merekomendasikan perlunya membuat kontrak secara tertulis (written contract) sehingga dokumen itu mengikat setiap elemen yang melakukan perjanjian. Pada sisi lain, perlu menyesuaikan waktu seleksi anggota dewan dengan periode jabatan lembaga legislatif daerah (DPRP).
\end{abstract}

Kata Kunci : Wilayah Adat, Anggota Dewan, DPRP, Kontrak Sosial dan Representasi

\begin{abstract}
.The special autonomous right of Papua as regulated in the Law No. 21/2011 has given particular rights to the region for establishing the Cultural Region Representative (DPWA) in the local legislative body. The composition of DPWA consists of the cultural community consisting of five cultural regions which are based on the proximity of geographical area and groups of tribes. The purpose of this article is to explain the phenomenon of the existence of the Dewan Adat (representative of local indigenous tribe) within the in the Papuan People's Representative Council (DPRP) in the perspective of social contracts according to Thomas Hobes, John Locke and J.J. Rousseau as well as in the perspective of representation proposed by Stuart Hall (2009). The purpose of this article is to explain the phenomenon of the existence of the Dewan Adat within the DPRP in the perspective of social contracts according to Thomas Hobes, John Locke and J.J. Rousseau and in the perspective of representation according to Stuart Hall (2009). This article is reviewed and analyzed by using qualitative methods where data is obtained through interviews, documents, journals, literature and online sources those are relevant to the object of the study. The findings of this study are explained that among the adat council, the representative council of indigenous territories and indigenous peoples as the three elements that carry out social contract agreements. The social contract carried out is made in an unwritten contract so that its legitimacy and existence are not that strong. Representation of the membership of the the Dewan Adat has theoretically met the criteria, which comes from the indegenous community, speaks on behalf of indigenous peoples and stands before indigenous peoples. This research then recommends the need to propose a written contract so that the document binds every element
\end{abstract}




\section{Keberadaan Perwakilan Wilayah Adat Di Dewan Perwakilan Rakyat Papua (DPRP) Dalam Perspektif Kontrak Sosial dan Dalam Perspektif Representasi Di Provinsi Papua (Nelwan Ronsumbre, Mohammad Benny)}

that makes the agreement. On the other hand, it is necessary to adjust the selection time of the board members with the term of office or tenure of the regional legislative body (DPRP).

Keywords: indigenous community, council members, papuan people's representative Council, social contracts and representations

\section{A. PENDAHULUAN}

Peraturan Daerah Khusus (Perdasus) Nomor 6 Tahun 2018 tentang Keanggotaan Dewan Perwakailan Rakyat Papua (DPRP) yang ditetapkan melalui mekanisme pengangkatan periode 2014-2019 sejalan dengan Undang-Undang Nomor 21 Tahun 2001 tentang Otonomi Khusus bagi Provinsi Papua Pasal 6 ayat (4) berbunyi: "Jumlah anggota Dewan Perwakilan Rakyat Papua (DPRP) adalah 11/4 (satu seperempat) kali dari jumlah anggota DPRD Provinsi Papua sebagaimana diatur dalam Peraturan Perundang-undangan.” Anggota Dewan Perwakilan Wilayah Adat (DPWA) yang ditetapkan melalui mekanisme pengangkatan ini berjumlah 14 orang yang merupakan perwakilan dari 5 daerah pengangkatan berdasarkan wilayah adat yang ditetapkan berdasarkan Perdasus ini pada pasal 14 sebagaimana dalam Tabel 1. berikut :

Tabel 1. Deskripsi Wilayah dan Jumlah Anggota

DPWA

\begin{tabular}{|c|l|c|}
\hline No & $\begin{array}{l}\text { Daerah } \\
\text { Pengangkatan } \\
\text { Kabupaten/Kota }\end{array}$ & $\begin{array}{l}\text { Jumlah } \\
\text { Anggota }\end{array}$ \\
\hline 1. & La Pago & 4 \\
\hline 2. & Mee Pago & 3 \\
\hline 3. & Ha Anim & 3 \\
\hline 4 & Tabi & 2 \\
\hline 5. & Saireri & 2 \\
\hline Jumlah & $\mathbf{1 4}$ \\
\hline
\end{tabular}

Sumber: Perdasus Nomor 6 Tahun 2018

Keberadaan anggota DPWA untuk pertama kali menduduki jabatan sebagai anggota Dewan di DPRP yang mekanisme keanggotaannya dilakukan melalui serangkaian proses yaitu masyarakat yang direpresenatsikan oleh oleh Dewan Adat (DA) memberikan rekomendasi atas beberapa orang yang dinilai layak untuk menduduki DPWA yang selanjutnya akan diseleksi melalui sebuah Tim dan Panitia Seleksi yang dibentuk DPRP. Unsur dari Panitia Seleksi ini terdiri atas Lembaga Swadaya Masyarakat, Akademisi dan Tokoh Agama. Panitia seleksi ini menetapkan sejumlah nama untuk selanjutnya disampaikan kepada Gubernur untuk ditetapkan sebagai anggota DPWA dalam kelembagaan DPRP. Penjelasan tentang legitimasi DPRP ditetapkan berdasarkan Keputusan DPRD Provinsi Papua Nomor 4/DPRD/2005 tentang Perubahan Nomenklatur Lembaga DPRD Provinsi Papua menjadi Dewan Perwakilan Rakyat Papua

Ada beberapa persoalan yang dihadapi oleh DPWA sehingga membuat mereka belum bisa menjalankan tugas dan fungsinya di lembaga legislatif. Persoalan dimaksud antara lain belum memadainya regulasi yang dibuat untuk menunjang eksistensi dewan ini disamping belum terbentuknya partai lokal sebagai wadah atau media untuk memberikan dukungan politik (backup) bagi eksistensi DPWA ini dalam lembaga legislatif lokal (DPRP).

Dari beberapa persoalan di atas, penelitian ini selanjutnya akan mengkaji eksistensi DPWA saat ini dilihat dalam persepektif kontrak sosial yang dikembangkan oleh Thomas Hobes, John Locke dan J.J. Rousseau dan pada perspektif representasi yang dikembangkan oleh Stuart Hall (2009). Di samping itu kajian ini juga akan memberikan proposal seperti apa layaknya DPWA ini ditempatkan dalam kelembagaan politik lokal termasuk mengenai penguatan fungsi dan perannya sebagai wakil dari masyarakat adat yang ada di Provinsi Papua.

Dalam penelitian terdahulu khususnya konsep kenegaraan dalam pemikiran politk Al-Mawardi (Sholehuddin, 2014:103-118). Hasil penelitiannya menunjukan bahwa relasi antara kalifah dan rakyat adalah kontrak sosial, perjanjian bersama untuk melakukan tugas dan kewajiban yang saling menguntungkan. Dengan demikian khalifah berhak ditaati oleh rakyat, tetapi juga berkewajiban melindungi dan bertanggungjawab sebagai imam. Teori ini terinsipirasi oleh Thomas Hobbes dan beberapa tokoh lainnya (Moh. Sholehuddin, 2014). Berdasarkan pemikiran tersebut, maka bagaimana unsur wilayah adat dalam membangun konsep kontrak sosial di dalam wilayah adat?

Penelitihan lainnya adalah proses rekruitmen kandidat Bupati Sleman yang dilakukan oleh PDI-P beserta perilaku partai yang selalu mendominasi di kursi legislatif Sleman yang dikaji oleh (Helmi Mahadi, 2011: 38-71). Hasil penelitian ini menunjukan kegagalan PDI$\mathrm{P}$ dalam mengusung kandidat dari internal partai adalah karena terjadinya pragmatism politik. Dalam konteks ini, pragmatism bersumber dari dua hal. Pertama, faktor internal, yaitu kegagalan kaderisasi PDI-P Sleman dan fenomena uang sebagai penentu perekrutan kandidat. Kedua, faktor eksternal, yaitu budaya politik masyarakat yang berpengaruh tidak secara langsung melalui presepsi elit terhadap kecenderungan pilihan publik (Helmi Mahadi, 2011). Dengan pemikiran ini, maka dapatkah beberapa elemen masyarakat dari wilayah adat ini akan menata konsep kontrak sosial?

Selanjutnya, penelitian tentang fenomena tentang varian perilaku elit Muhammadiyah terkait dengan pemilihan kepada daerah yang diselenggarakan 
di Banyuwangi yang diteliti oleh (Muklis, 2015:21-39). Terdapat dua pertanyaan yang ingin dijawab dalam kajian ini. Pertama, apa yang melatarbelakangi beragam varian elit politik Muhammadiyah dalam pemilihan kepala daerah? Kedua, apa makna dibalik perilaku elit Muhammadiyah tersebut?. Unit analisis dalam kajian ini adalah individu yakni anggota muhamadiyah yang memiliki posisi sebagai pemimpin muhammadiyah. Dari penelitian ini dikemukakan bahwa, Muhammadiyah dalam membaca persoalan politik lokal, berpijak pada dokumen kepribadian Muhammadiyah yang di dalamnya terdapat panduan ideologis dalam menghadapi situasi politik. Kendati demikian, para elit Muhammadiyah terkadang memiliki kepentingan pragmatis masing-masing. Karena itu, di antara elit yang satu dengan yang lain, memiliki pilihan politik yang berbeda. Namun, perbedaan politik itu jelas, dalam koridor etis pilihan rasional dan nilai-nilai moral Muhammadiyah (Muklis, 2015). Melalui kajian dalam fenomena ini, bagaimana orang papua dalam beberapa unsur di wilayah adat akan membentuk konsep kontrak sosialnya untuk mendukung anggota DPWA di kelembagaan DPRP?

\section{B. PERUMUSAN MASALAH}

Berdasarkan latar belakang di atas maka yang menjadi rumusan masalah dalam kajian ini adalah bagaimana keberadaan DPWA dalam perspektif kontrak sosial dan representasi dalam kelembagaan legislatif lokal (DPRP)?

\section{METODE PENELITIAN}

Metode penelitian yang digunakan adalah deskriptif kualitatif. Metode penelitian deskriptif kualitatif adalah metode untuk menyelidiki obyek yang tidak dapat diukur dengan angka-angka ataupun ukuran lain yang bersifat eksak menurut Strauss dan Corbin dalam Cresswell, J. (1998:24).

Penelitian kualitatif juga bisa diartikan sebagai riset yang bersifat deskriptif dan cenderung menggunakan analisis dengan pendekatan induktif Data yang digunakan dalam penelitian ini adalah wawancara dan data sekunder berupa buku, jurnal, laporan penelitian atau berita yang diterbitkan oleh media yang kredibel. Analisis data yang digunakan adalah analisis data kualitatif yaitu analisa yang menekankan kepada kualitas dan bukan kuantitas dari objek yang dikaji dalam penelitian ini.

\section{PENDEKATAN TEORI}

Berdasarkan perumusan masalah di atas maka peneliti melakukan pendekatan teoritis berdasarkan dua teori pokok yaitu teori kontrak sosial yang dibicarakan oleh Thomas Hobbes, John Locke dan Jean Jacques Rousseau dan teori representasi yang dikembangkan oleh Stuart Hall (2009).
Ide awal pemikiran Thomas Hobbes dan John Locke tidak terlepas dari realitas bahwa mereka saksi atas pergolakan politik Inggris mulai dari Revolusi Puritan 1648 dan Revolusi Kejayaan 1688 (Wijaya, 2016:183-193). Banyaknya korban akibat perang serta penindasan membuat mereka berusaha mencari solusi alternatif. Mereka sepertinya berkolaborasi dalam mencapai tujuan yang sama namun dengan mengambil cara yang berbeda. Hal ini didasari atas perbedaan asumsi diantara keduanya. Jika Hobbes menganggap bahwa manusia adalah serigala bagi manusia (zoon politicon) manusia lainnya maka Locke memandang manuia layaknya selembar kertas putih tanpa noda. Keadaan perang menurut keduanya adalah cara untuk mencari solusi tersebut. Mereka tampaknya sepakat untuk merekomendasikan kontrak sosial (social contract) sebagai jalan damai dimana negara akan memberikan jaminan akan keadilan dan kesejahteraan rakyat (Wijaya, 2016).

Berdasarkan pemikiran Hobbes dan Locke tentang konteks kontrak sosial, peranan yang dilakukan oleh Dewan Adat sebagai pencipta kepercayaan (trustor) dan anggota perwakilan wilayah adat di Dewan Perwakilan Rakyat Papua (DPRD) sebagai penerima kepercayaan (trustee) dan masyarakat adat sebagai penerima manfaat kepercayaan (beneficieries) belum jelas bagaimana pelaksanaannya sehingga perlu dilakukan kajian lebih lanjut.

Thomas Hobbes memandang bahwa manusia mempunyai sifat dasar yang sama yakni sama-sama memiliki keinginan atau kepentingan dan ketidaksukaan terhadap suatu hal (Susilo, 1988). Dalam keadaan tertentu, kepentingan dan ketidaksukaan antar manusia ini saling berbenturan sehingga ada pihak yang mendominasi pihak lain. Kemudian terjadi usaha seseorang untuk berada diatas orang lain, yang akhirnya dimungkinkan terjadinya perang dan kondisi menjadi tidak aman. Maka, untuk menghasilkan situasi aman yang terjamin, mereka menyerahkan kepercayaan mereka kepada sebuah lembaga yang dapat menjamin keamanan, kestabilan, dan kesejahteraan mereka melalui sebuah kesepakatan. Kesepekatan inilah yag disebut kontrak sosial. Dalam hal ini lembaga yang memegang kedaulatan tersebut menjamin hak-hak masyarakat, tanpa harus ada akuntabilitas kepada masyarakat, dengan anggapan bahwa masyarakat telah memberikan kepercayaan kepada lembaga tersebut melalui kontrak sosial (Susilo, 1988).

Berbeda dengan Hobbes, John Locke mengasumsikan manusia pada dasarnya sama antara yang satu dengan lainnya. Namun, manusia bisa menentukan mana yang benar dan salah, sehingga tidak perlu khawatir untuk mengganggu kehidupan manusia yang lain. Akan tetapi, ketika pikiran baik tadi disertai dengan nafsu, maka akan menjadi tidak terkontrol dan melanggar hak-hak orang lain. Padahal manusia tidak punya cukup kekuasaan untuk main hakim sendiri 
terhadap sesamanya. Sehingga masih terdapat potensi terjadinya ketidakamanan. Maka manusia lagi-lagi menyerahkan haknya dalam hal ini sebagian kepada pihak yang diajak membuat kontrak sosial untuk menjamin keamanan mereka. Karena hanya sebagian, maka masyarakat masih bisa melakukan kontrol terhadap pemegang kekuasaan.

Menurut Locke, ada tiga pihak dalam kontrak sosial ini, yaitu pencipta kepercayaan (the trustor), yang diberi kepercayaan (the trustee) dan yang menerima manfaat dari pemberian kepercayaan (the beneficiary) (Susilo,1988). The trustee adalah pemerintah atau pemegang kekuasaaan dimana mereka bertanggung jawab terhadap beneficiaries. Sedangkan Rousseau menganggap bahwa sifat dasar manusia adalah saling bekerjasama, sehingga tidak terjadi perkelahian. Sifat saling bekerja sama ini biasanya tertampung dalam sebuah organisasi, sehingga akhirnya muncul seseorang yang mendominasi dan memiliki hakhak istimewa sehingga berpotensi terjadi kekuasaan tunggal (Susilo, 1988). Untuk menghindari kekuasaan tunggal ini, maka perlu dibentuk sebuah kontrak sosial dalam masyarakat. Dalam masyarakat terdiri atas kehendak bebas dan kehendak umum. Kehendak bebas ini mengedepankan kehendak-kehendak pribadi masyarakat sedangkan kehendak umum lebih mengedepankan pada keputusan terbaik yang dapat diperoleh masyarakat. Sehingga masyarakat harus mengikuti apa yang menjadi kehendak umum karena ini sudah merupakan keputusan yang terbaik. Dan Rousseau menilai bahwa kehendak umum ini merupakan tugas dari lembaga legislatif untuk menentukan keputusan yang terbaik bagi masyarakat.

Jadi, dapat disimpulkan bahwa kontrak sosial dilakukan untuk menjamin keamanan dan kesejahteraan masyarakat yang disebabkan ketakutan masyarakat akan adanya ketidakseimbangan akibat perbenturan kepentingan-kepentingan manusia jika tidak ada yang mengawasi.

Representasi adalah proses dimana sebuah objek ditangkap oleh indra seseorang, lalu masuk ke akal untuk diproses yang hasilnya adalah sebuah konsep/ide yang dengan bahasa akan disampaikan/diungkapkan kembali. Menurut Stuart Hall dalam bukunya Representation: Cultural Representation and Signigying Practices, "Representation connect meaning and language to culture .... Representation is an essential part of the process by which meaning is produced and exchanged between members of culture" (Stuart Hall, 2003:17). Melalui representasi, suatu makna diproduksi dan dipertukarkan antar anggota masyarakat.

Jadi dapat dikatakan bahwa, representasi secara singkat adalah salah satu cara untuk memproduksi makna. Representasi bekerja melalui sistem representasi. Sistem representasi ini terdiri dari dua komponen penting, yakni konsep dalam pikiran dan bahasa. Kedua komponen ini saling berelasi. Konsep dari sesuatu hal yang kita miliki dalam pikiran kita, membuat kita mengetahui makna dari hal tersebut. Namun makna tidak akan dapat dikomunikasikan tanpa bahasa. Yang terpenting dalam sistem representasi ini pun adalah bahwa kelompok yang dapat berproduksi dan bertukar makna dengan baik adalah kelompok tertentu atau memiliki suatu latar belakang pengetahuan yang sama sehingga dapat menciptakan suatu pemahaman yang (hampir) sama. Menurut (Stuart Hall, 2003:17) "member of the same culture must share concepts, images, and ideas which enable them to think and feel about the word in roughly similar ways. They must share, broadly speaking, the same 'cultural codes'. In this sense, thinking and feeling are themselves 'system of representation'. Berpikir dan merasa menurut Hall juga merupakan sistem representasi. Sebagai sistem representasi berarti berpikir dan merasa juga berfungsi untuk memaknai sesuatu.

Oleh karena itu, untuk dapat melakukan hal tersebut, diperlukan latar belakang pengalaman yang sama terhadap konsep, gambar dan ide (cultural codes). Pemaknaan terhadap sesuatu dapat sangat berbeda dalam budaya atau kelompok masyarakat yang berlainan karena masing-masing budaya atau kelompok masyarakat tersebut ada cara-cara tersendiri dalam memaknai sesuatu. Kelompok masyarakat yang memiliki latar belakang pemahaman yang tidak sama terhadap kode-kode budaya tertentu tidak akan dapat memaknai makna yang diproduksi oleh kelompok masyarakat lain. Makna tidak lain adalah suatu kontruksi. Manusia mengkontruksi makna dengan sangat tegas sehingga suatu makna terlihat seolah-olah alamiah dan tidak dapat diubah. Makna dikontruksi melalui sistem representasi dan difikasi melalui kode. Kode inilah yang membuat masyarakat yang berada dalam suatu kelompok budaya yang sama mengerti dan menggunakan nama yang sama, yang telah melewati proses konvensi secara sosial. Menurut Stuart Hall dalam artikelnya, "Things don't mean: we construct meaning, using representational system concepts and signs". Oleh karena itu konsep (dalam pikiran) dan tanda (bahasa) menjadi bagian penting yang digunakan dalam proses konstruksi atau produksi makna (Ahmad, 2009)

\section{E. PEMBAHASAN}

1. Keberadaan anggota Perwakilan Wilayah Adat Di Dewan Perwakilan Rakyat Papua (DPRP) dalam Perspektif Kontrak Sosial.

Dalam mendeskripsikan keberadaan anggota DPWA dalam kelembagaan DPRP pada perspektif kontrak sosial dapat dilihat melalui fenomena diantaranya bagaimana kandidat berusaha dalam memenangkan pemilu, sehingga dapat mengikat calon kandidat atas masyarakat pemilihnya untuk 
menghasilkan trust yang didefenisikan oleh Fukuyama sebagai harapan terhadap keteraturan, kejujuran, dan kerja sama yang hadir di dalam masyarakat, dan bertolak dari norma-norma yang dihadirkannya dalam kehidupan sehari-hari (Sanit, 2004:3-8). Norma yang berakar kepada nilai luhur dikembangkan menjadi kode dan atruan bersikap serta perilaku sebagai orang terhormat jujur dan adil. Untuk merealisasikan trust di dalam pemilu sebagai kontrak sosial, masyarakat yang berpengalaman dengan demokrasi lazimnya menggunakan kesepakatan terhormat (gentlemen agreement) yang terdiri dari pemberian suara kepada calon sebagai tanda persetujuan pemilih atau figur dan program calon. Karena belum melembaganya "persetujuan terhormat" di antara calon atau kandidat maka calon terpilih yang berupaya menepati janji, tetapi cenderung besar gagal karena melebihi kemampuan politisi, negarawan, dan manajerial politik yang dimiliki. Ada pula karena sistem politik dan pemerintahan tidak mendukung upayanya dan kebanyakan karena gabungan kedua alasan tersebut. Selain dari alasan-alasan tersebut tidak dapat dipungkiri adanya kandidat terpilih yang tidak memahami seluk beluk demokrasi, termasuk kewajibannya menepati janji pemilu. Dalam rangka itulah muncul wacana tentang perlunya kontrak sosial di antara pemilih dengan yang dilakukan dengan calon yang diajukan dalam pemilu. (Arbi Sanit, 2004).

Kontrak sosial yang dibuat oleh ketiga elemen seperti disebutkan di atas masih belum dibuat secara tertulis (unwritten contract) seperti penuturan informan berikut ini:

"Perjanjian dengan masyarakat adat di 5 (lima) wilayah adat yang kami Anggota 14 kursi DPRP wakili hanya dalam bentuk perjanjian dan pernyataan lisan yang masing-masing kami sampaikan dalam musyawarah adat saat itu di suku masing-masing," (Wawancara dengan YLR tanggaL 20 November 2018 pukul 12.27 WIB).

Dalam teori kontrak sosial kehadiran anggota DPWA tidak terlepas dari konteks masyarakat adat yang secara regulatif diakui keberadaanya melalui konstitusi dasar negara khususnya pada Pasal 18 B Ayat 2 (Sabardi,2013: 170-196). Konsep masyarakat itu sendiri menurut pemahaman Soekanto (2004:204) paling tidak dicirikan oleh 4 (empat) hal yaitu: (i) setiap anggota kelompok tersebut harus sadar bahwa dia merupakan sebagian dari kelompok yang bersangkutan, (ii) ada hubungan timbal balik antara anggota yang satu dengan anggota lainnya, dalam kelompok itu, (iii) ada suatu faktor yang dimiliki bersama oleh anggota-anggota kelompok itu sehingga hubungan antara mereka bertambah erat dan (iv) berstruktur, berkaidah dan mempunyai pola perilaku.

\section{Keberadaan Anggota DPWA Dalam Kelembagaan DPRP Dalam Perspektif Representasi.}

Anggota DPWA ditentukan dengan memperhatikan persyaratan yang ketat sebagaimana diatur dalam Perdasus Nomor 6 Tahun 2018 Pasal 37. Persyaratan keanggotaan itu antara lain menyangkut domisili kandidat yang harus berada dalam 5 wilayah adat Papua, berusia paling rendah 21 tahun, pendidikan minimal SLTA sederajat, tidak berprofesi sebagai PNS/TNI/Polri dan persyaratan kompetensi dan integritas lainnya.

Berdasarkan ketentuan Perdasus Nomor 6 Tahun 2018 penentuan Anggota DPWA pada setiap daerah pengangkatan diuraikan dalam Tabel 2. Berikut ini:

Tabel 2. Komposisi Anggota DPWA Berdasarkan

\section{Daerah Pengangkatan}

\begin{tabular}{|c|c|c|}
\hline No & $\begin{array}{l}\text { Daerah Pengangkatan } \\
\text { Kabupaten/Kota }\end{array}$ & $\begin{array}{l}\text { Jumlah } \\
\text { Anggota }\end{array}$ \\
\hline \multirow[t]{2}{*}{1.} & \multicolumn{2}{|l|}{ La Pago } \\
\hline & $\begin{array}{l}\text { Jayawijaya, Puncak Jaya, Puncak, } \\
\text { Tolikara, Lani Jaya, Nduga, } \\
\text { Pegunungan Bintang, } \\
\text { Mamberamo Tengah, Yalimo dan } \\
\text { Yahukimo }\end{array}$ & 4 \\
\hline \multirow[t]{2}{*}{2.} & \multicolumn{2}{|l|}{ Mee Pago } \\
\hline & $\begin{array}{l}\text { Nabire, Paniai, Deyai, Dogiai, } \\
\text { Intan Jaya dan Mimika }\end{array}$ & 3 \\
\hline \multirow[t]{2}{*}{3.} & \multicolumn{2}{|l|}{ Ha Anim } \\
\hline & $\begin{array}{l}\text { Merauke, Mapi, Asmat dan } \\
\text { Boven Digoel }\end{array}$ & 3 \\
\hline \multirow[t]{2}{*}{4} & \multicolumn{2}{|l|}{ Tabi } \\
\hline & $\begin{array}{l}\text { Kota Jayapura, Jayapura, } \\
\text { Keerom dan Sarmi }\end{array}$ & 2 \\
\hline \multirow[t]{2}{*}{5.} & \multicolumn{2}{|l|}{ Saireri } \\
\hline & $\begin{array}{l}\text { Mamberamo Raya, Waropen, } \\
\text { Kepulauan Yapen, Biak Numfor } \\
\text { dan Supiori }\end{array}$ & 2 \\
\hline \multicolumn{2}{|c|}{ Jumlah } & 14 \\
\hline
\end{tabular}

Sumber: Perdasus Nomor 6 Tahun 2018

Dasar penentuan wilayah dan alokasi kursi pada masing-masing daerah pengangkatan utamanya didasarkan atas kesamaan wilayah adat atau sub etnik yang sama, wilayah geografis yang berdekatan dan juga memperhatikan jumlah penduduk yang ada pada masing-masing wilayah. 


\section{Keberadaan Perwakilan Wilayah Adat Di Dewan Perwakilan Rakyat Papua (DPRP) Dalam Perspektif Kontrak Sosial dan Dalam Perspektif Representasi Di Provinsi Papua (Nelwan Ronsumbre, Mohammad Benny)}

\section{Gambar 1. Peta Pembangian Wilayah Masyarakat Adat}

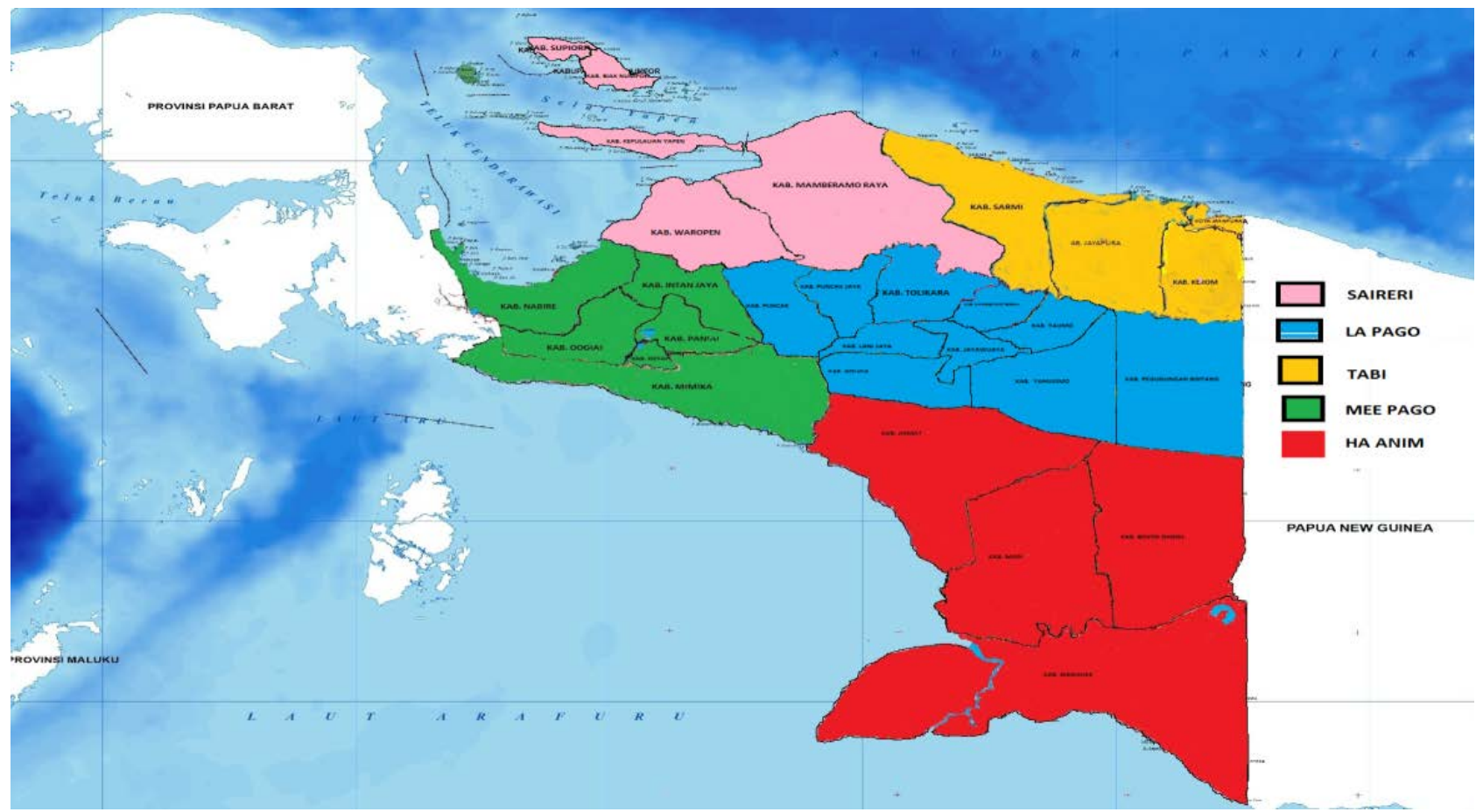

Sumber: Peneliti, 2018

Pentingnya Informasi Wilayah Adat termaktub dalam Peraturan Menteri Dalam Negeri No. 52 tahun 2014 tentang Pedoman Pengakuan dan Perlindungan Masyarakat Hukum Adat, di dalamnya tercantum ketentuan bagi masyarakat adat yang terdiri atas : a) sejarah Masyarakat Hukum Adat; b) wilayah Adat; c) hukum Adat; d) harta kekayaan dan/atau benda-benda adat; dan e) kelembagaan/sistem pemerintahan adat. Undang-Undang No. 6 tahun 2014 tentang Desa mensyaratkan ada kejelasan hubungan genelogis atau ikatan darah dan kejelasan wilayah adat. Mengacu pada kedua regulasi diatas, maka kejelasan informasi mengenai wilayah adat menjadi syarat penting untuk mendapatkan pengakuan.

Setelah pengangkatan Anggota DPWA ini dan penempatannya pada DPRP, mereka dapat bergabung dengan fraksi yang ada di DPRP dan mereka juga dapat bergagung atau ditunjuk untuk menjadi anggota pada alat kelengkapan DPRP seperti menjadi anggota Badan Musyarah, Komisi-Komisi, Badan Legislasi, Badan Anggaran dan sebainya sebagaimana diatur pada Pasal 46 Perdasus Nomor 6 Tahun 2014. Demikian halnya dengan hak keuangan yang mereka peroleh akan berlaku sama dengan anggota DPRP lainnya yang berasal dari partai politik. Namun untuk menjadi pimpinan pada alat kelengkapan DPRP tersebut, regulasi belum memberikan peluang untuk itu.

Permasalahan representasi anggota DPWA dalam kelembagaan DPRP tidak terlepas dari adanya resistensi dari berbagai elemen di Papua. Eksistensi tentang keberadaan 14 kursi dari Dewan Adat antara lain datang dari Forum Persatuan Masyarakat Lima Adat Papua antara lain yang mempertanyakan keaslian anggota sebagai warga papua dan juga mekanisme penunjukan yang tidak selaras antara kepanitiaan yang dibentuk dan keputusan penentuan anggota. Resistensi lainnya adalah kritikan salah satu partai politik yang menganggap eksistensi keanggotaan mereka illegal karena tidak dilakukan mekanisme penunjukan sesuai prosedur seperti adanya anggota partai politik yang terpilih menjadi anggota DPWA. Pada kesempatan lain, banyak partai politik mempertanyakan legalitas pengangkatan, ketersediaan anggaran dan masalah protokoler yang belum jelas untuk keberadaan 14 anggota DPWA tersebut.

\section{F. SIMPULAN DAN REKOMENDASI}

Perwakilan wilayah adat di Dewan Perwakilan Rakyat Papua (DPRP) tidak dapat mengartikulasikan tugas dan fungsi idealnya sebagai anggota legislatif dan juga sebagai penerima kepercayaan dari masyarakat adat yang diwakilinya. Salah satu persoalan penting yang dihadapi oleh perwakilan masyarakat adat adalah persistensi anggota legislatif yang diwakili oleh partai politik terhadap eksistensi mereka serta lamanya proses pengangkatan keanggotaan perwakilan masyarakat adat ini. Persoalan lainnya juga menyangkut belum termanifestasinya kehadiran partai politik lokal yang dapat menjembatani kepentingan masyarakat Papua secara umum dan masyarakat adat secara khusus. 
Penelitian ini selanjutnya merekomendasikan beberapa hal diantaranya perlunya komitmen anggota DPWA untuk memperjuangkan hak-hak dan kepentingan masyarakat adat baik melalui lembaga legislatif maupun melalui saluran politik lainnya. Pemerintah Papua melalui gubernur perlu melakukan penyesuaian masa pengangkatan anggota DPWA dengan keanggotaan legislatif dari unsur partai politik sehingga mereka bisa bekerja efektif dan bersamaan dengan anggota DPRP yang berasal dari unsur partai politik. Disamping itu, Perdasus Nomor 6 Tahun 2014 perlu direvisi sehingga memungkinkan anggota legislatif dari unsur DPWA memiliki hak dan kesempatan untuk menduduki jabatan pimpinan pada lembaga legislatif Provinsi termasuk pada komisi maupun alat kelangkapan dewan.

\section{DAFTAR PUSTAKA}

\section{Buku}

Cresswell, J. 1998. Research Design: Qualitative Research for Education. Boston, MA: Allyn and Bacon.

Soekanto, Soerjono (2014) osiologi Suatu Pengantar, Jakarta: PT RajaGrafindo Persada.

Stuart Hall. "The Work of Representation." Representation: Cultural Representation and Signigying Practices. Ed. Stuart Hall. London : Sage Publication, 2003.

Susilo, I. Basis. 1988. Teori Kontrak Sosial dari Hobbes, Locke, dan Rosseau dalam Jurnal Masyarakat, Kebudayaan, dan Politik. Surabaya: FISIP Unair http://www.essortment.com/john-lockes-socialcontract-theoy-46748.html.

\section{Jurnal}

Ahmad, Nurzakia (2009) Representasi Maskulinitas. Jakarta: FIB UI

Arbi Sanit. 2004. Kontrak Sosial dan Pemilihan Umum. Jurnal Penelitian Politik. Volume 1, Nomor 1, 2004: 2-8.

Helmi Mahadi, 2001. Pragmatisme Politik: Studi Kasus Proses Rekrutmen Politik PDIP Pada Pilkada, Kabupaten Sleman. Http://dx.doi.org/10.18196/jgp.2011.0004.

Moh. Sholehuddin. 2014. Konsep Kenegaraan Dalam Pemikiran Politik Al-Mawardi. Jurnal Review Politik. Volume 04, Nomor 1, Juni 2014.

Muklis, 2015. Perilaku Politik Elit Keagamaan dalam Politik Lokal. Jurnal SALAM volume 18 Nomor 1, Halaman 1 - 183, Malang, Juni 2015.
Sabardi, Lalu (2013) Konstruksi Makna Yuridis Masyarakat Hukum Adat Dalam Pasal 18 B UUD 1945 Untuk Identifikasi Adanya Masyarakat Hukum Adat. Jurnal Hukum Dan Pembangunan Tahun Ke-43 No.2 April-Juni 2013 Pp. 170-196

Wijaya, Daya Negri (2016) Kontrak Sosial Menurut Thomas Hobbes dan John Locke. Jurnal Sosiologi Pendidikan Humanis Volume 1, Nomor 2, Desember 2016, pp. 183-193.

\section{Dokumen}

Peraturan Daerah Khusus (Perdasus) Nomor 6 Tahun 2014 tentang Keanggotaan Dewan Perwakilan Rakyat Papua yang ditetapkan melalui mekanisme pengangkatan.

Permendagri Nomor 52 Tahun 2014 tentang Pedoman Pengakuan dan Perlindungan Masyarakat Hukum Adat.

Undang-Undang Dasar 1945 (Pasal 18 B)

Undang-Undang Nomor 21 Tahun 2001 tentang Otonomi Khusus bagi Provinsi Papua.

Undang-Undang Nomor 6 Tahun 2014 tentang Desa.

\section{Sumber Lain}

http://brwa.or.id/news/read/252 diakses tanggal 28 November 2018 pukul 05.04.

http://dpr-papua.go.id/profil/sejarah-dpr-papua/ diakses tanggal 19 November 2018 pukul 01.16 WIB

http://kawattimur.com/2017/12/13/hanura-tuding-14-kursiotsus-di-parlemen-papua-ilegal/ diakses tanggal 13 November 2018 pukul $14.11 \mathrm{Wib}$

http://lintaspapua.com/2017/12/13/minta-ditundaempat-fraksi-tolak-pelantikan-14-kursi-dprpapua/ diakses tanggal 13 November 2018 pukul $16.00 \mathrm{Wib}$

https://www.google.co.id/search?q=definisi+representa si\&oq=defenisi+representasi\&aqs=chrome.1.69i 57j015.9077j1j7\&sourceid=chrome\&ie=UTF-8 diakses tanggal 20 November 2018 pukul 21.40 WIB.

https://www.google.co.id/search?q=Penelitian+kualitat if +juga+bisa+diartikan+sebagai+riset+yang+ber sifat+deskriptif+dan+cenderung+menggunakan+ analisis+dengan+pendekatan+induktif\&oq=Pene $\underline{\text { litian+kualitatif+juga+bisa+diartikan+sebagai+ri }}$ set+yang+bersifat+deskriptif+dan+cenderung+ menggunakan+analisis+dengan+pendekatan+ind uktif\&aqs=chrome..69i57.1418j0j7\&sourceid $=$ c $\underline{\text { hrome\&ie=UTF-8 di akses tanggal } 28 \text { November }}$ 2018 pukul 04.16 WIB. 
Keberadaan Perwakilan Wilayah Adat Di Dewan Perwakilan Rakyat Papua (DPRP) Dalam Perspektif Kontrak Sosial dan Dalam Perspektif Representasi Di Provinsi Papua

(Nelwan Ronsumbre, Mohammad Benny)

https://www.jawapos.com/jpg-

today/12/10/2016/digugat-soal-14-kursi-dprd-

begini-tanggapan-gubernur-papua diakses

tanggal 12 November 2018 pukul 19.00 WIB. 